\title{
Ibn al-Khațīb and His Mamluk Reception
}

\author{
Victor de Castro León
}

\section{1 \\ Ibn al-Khațīb and His Context*}

Every scholar working on the history of the Islamic West is familiar with the life and works of the Granadian polymath Ibn al-Khatiib (714-76/1313-74), while maybe that is not the case with those working on other regions, mainly the Islamic East. For this reason, it is important to briefly introduce this famous Western scholar. He was born in Loja (Granada) in November 714/1313. Educated in all the subjects and knowledge of his time, he became the famous secretary and head of the chancellery and a powerful vizier of the Nașrid kingdom of Granada during the period of its greatest splendor: the reigns of Sultan Yūsuf I (r. 733-54/1333-54) and his son Muhammad v (754-6o/1354-9, 763$93 / 1362-91)$. In the year $772 / 1371$, tired of the courtly work and worn out by a lifetime full of power, ambitions, conspiracies, intrigues, and personal misfortunes, he decided to escape from the kingdom of Granada toward the Merinid kingdom of Fez of the Sultan 'Abd al-'Azīz (r. 768-74/1366-72). Ibn al-Khațîb spent the last years of his life under the latter's protection, and subsequently under that of his minor son Muhammad al-Sa'id IV (r. 774-6/1372-4) and his powerful vizier Ibn Gāzī, while he was accused in Granada of treason, disloyalty, and heresy. In the year 776/1374, a series of adverse events finally led his adversaries from Granada, and also from the Maghreb, to get Ibn al-Khațîb imprisoned and murdered in prison.

From a historical point of view, Ibn al-Khațī ${ }^{1}$ is the most important Nașrid polymath, the author of many books on different topics (Sufism, law, poetry,

* This work has been carried out within the research project "Local contexts and global dynamics: Al-Andalus and the Maghreb in the Islamic East (AMOI)," funded by the Ministry of Economy of Spain (FFI2O16-78878-R) and codirected by Maribel Fierro (ILC-CSIC) and Mayte Penelas (EEA-CSIC).

I want to express my gratitude to Professor Josef Zenka (Charles University, Prague) for the important indications and information that he has given to me and also to Maribel Fierro (CCHS-CSIC, Spain) for her help and support in the redaction of this study.

1 There are many studies in relation to the life and work of Ibn al-Khațib. For a general perspective, see Lirola Delgado, Ibn al-Jațîb; Robinson, Lisān al-Dīn; Vidal Castro, Ibn al-Khațīb; Ballan, Scribe. 
history, medicine, astronomy, and geography), and a man who also played a crucial political role in the development of the Nașrid kingdom. In his time and after his death, his fame went beyond the Maghreb, and he became renowned, especially in Mamluk Egypt, for reasons that I will try to explain in this paper.

In a general context, ${ }^{2}$ it is important to have in mind the situation of alAndalus, especially after 608/1212, with the defeat of the Almohads in the Battle of Las Navas de Tolosa, and consequently the unstoppable advance of the Christian conquest of the Andalusian territory. So, the 13th-century progressive territorial Muslim loss in the Iberian Peninsula increased the wave of Andalusi emigration to North Africa and the East. This had already begun in previous centuries, but now those who emigrated not only went in search of knowledge or pilgrimage but also a new life. The diplomatic and political relationships between al-Andalus and North Africa with the Islamic states of the East also increased. The feeling of loss and the end of Western Islam caused a growing concern among the Andalusi emigrants about the preservation of their culture, which explains not only the diffusion of Maghrebi works in the East but also the increase in the composition of anthologies of every kind in order to gather all this intellectual Andalusi heritage. This regret was maintained until after the expulsion of the Moriscos of Spain (1019/1611), ${ }^{3}$ as attested by the scholar Tlemcen al-Maqqarī (d. 1041/1632), who composed his famous anthology Naf̣ al-țīb in memory of al-Andalus's past and at the request of the Damascus 'ulam $\vec{a}^{\text {' }}$ desiring to know the glories of al-Andalus. ${ }^{4}$

At the same time, in this period of territorial regression and ideological exaltation of Islam that took place in the Western Muslim kingdoms, caused in part by the Christian threat, authors of written works had become increasingly concerned about issues of authorship, plagiarism, and fame. This was the case with the Granadian historian Ibn al-Khațib but also with other authors, like Ibn Sacīd al-Maghribī, Ibn al-Abbār, Ibn Ḥayyān al-Gharnāṭ̄, Ibn Bațtūṭa, Ibn Marzūq, Ibn Khaldūn, and many others. This involved not just Westerners, but also Easterners, including Mamluk scholars such as al-Suyūțī, al-Maqrīzī, and al-Sakhāwī, some of whom were accused of plagiarism (we know that al-Suyūṭi wrote a small treatise criticizing plagiarism entitled al-Fāriq bayna al-mușannif wa-l-sāriq). ${ }^{5}$

Ibn al-Khațib can be said to have been "obsessed" with the ambition to make his works known to an audience beyond al-Andalus and the Maghreb.

2 For a general view of the Nașrid kingdom, see Viguera Molíns, El reino.

3 Velázquez Basanta, Relación, 481-554.

4 Elger, Adab, 289-3o6.

5 Al-Suyūțī, al-Fāriq, 27-9; Bauden, Should, 159-232. 
His privileged position in the court as secretary and vizier of the Nașrid kingdom, especially with Sultan Muhammad v, allowed him to establish an extended network of personal and diplomatic relationships that contributed to the spread of his work. Recent studies ${ }^{6}$ have shown the importance of the network of "intellectual kinship" that united scholars across the political divisions of the Islamic world. This cultural network-established mainly through the teaching method of the $i j \overline{a z a s}$ - was fundamental in the intellectual, cultural, and political development of the Islamic world, especially in the 14th and 15th centuries. ${ }^{7}$ In this study, I will try to situate Ibn al-Khațīb in such a network by putting together hitherto scattered or ignored data in order to recover the ways in which he succeeded in making some of his works travel beyond the limits of the Maghreb, especially in Mamluk Egypt. For this purpose, we will focus mainly on two Maghrebi personalities from Ibn al-Khațîb's network who settled in Cairo. One is well known for his relationship with the Granadian vizier, the Tunisian Ibn Khaldūn. On the other hand, hardly anything is known about the Tlemecene Ibn Abī Ḥajala's relationship with Ibn al-Khațîb and his fundamental role in the dissemination of his works. For the study of this triple relationship, we will present testimonies that show us how this network took place and the reception and use of Ibn al-Khațib's works by these two authors in Mamluk Cairo. Finally, we will mention other Mamluk authors who knew and used the works of the Granadian polymath, with special reference to the Tlemecene author of the 17th century, al-Maqqarī.

In a general way, we can say that Ibn al-Khațîb employed some means at his disposal to make his works known. We are aware that he participated in many diplomatic embassies to the Maghreb and North Africa, ${ }^{8}$ sent letters to Mamluk sultans and Medina and Mecca amirs, ${ }^{9}$ and also had an attorney in Egypt, Abū 'Amr b. al-Ḥājj al-Numayrī, who was his trusted person in those territories. ${ }^{10}$

6 See Fromherz, Ibn Khaldūn, 288-305; Binbas, Intellectual, $1-75$.

7 In the case of Ibn al-Khațîb, the diffusion through the ijāzas was very important, but Lisan's contemporaries, such as Ibn al-Ḥajj al-Numayrī, Ibn Hiizb Allah, and some others spread across the Maghreb and with them their works. See Ženka, 306-39.

8 Jreis Navarro, El extraño, 81-10o.

9 Ibn al-Khațib recognizes in one of his works that due to the great pressure of the Christian kingdoms, it was important to do everything possible to get the help of the Muslim kingdoms of the East, especially once relations with the North African kingdoms got colder at the end of the reign of Muhammad v. In this sense, we can also understand the diffusion of his works from a political point of view. See Ibn al-Khațīb, Kitāb i, 320.

10 In relation to his famous brother, the poet of the Nașrid court; see Lirola Delgado and López, Ibn al-Ḥâŷy iii, 642-3. 
Ibn Abī Hajala (1325-75), ${ }^{11}$ a scholar from Tlemcen who settled in Egypt ${ }^{12}$ and who was always aware of the situation in the Maghreb and al-Andalus, maintained a fluid correspondence with Ibn al-Khațīb and was the main recipient of his work in Cairo. It all started when Ibn Abī Hajala sent Sultan Muhammad v in Granada a copy of his celebrated work Diwwān al-ṣabāba, approximately around $767 / 1365$. The book was well received and much talked about, leading to Ibn alKhațīb being challenged to reply with another work. ${ }^{13}$ Ibn al-Khațîb accepted the challenge and composed his work Rawdat al-ta'riff, based on divine love in opposition to the carnal and passionate love of the Diwān al-ṣabāba, as Ibn alKhațīb himself explains in the prologue of his Raw a $^{14}$

$$
\begin{aligned}
& \text { اما بعد, فإنة لما ورد على هذه البلاد الاندلسية ... ديوان الصبابة, و هو الموضوع الذي اشتمل } \\
& \text { من ابطال العشاق على الكثير, و استوعب من اقوالهم الحديثه و القديمة كل نظيم و نثير ... و }
\end{aligned}
$$

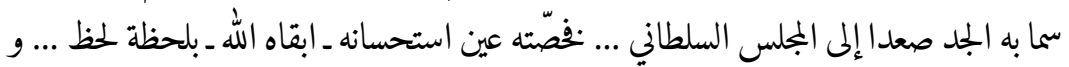

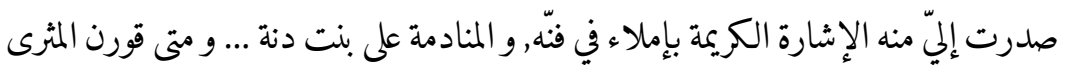

$$
\begin{aligned}
& \text { بالمترب, او وزن المشرق بالمغرب؟ شتان بين من تُجلى الشمس منة فوق منصتها, و بين من }
\end{aligned}
$$

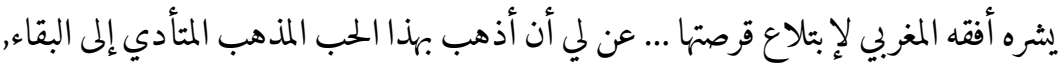

$$
\begin{aligned}
& \text { الموصل إلى ذروة السعادة في معارج الإرتقاء ... حب الله الموصل إلى قربه. }
\end{aligned}
$$

When he came to al-Andalus ... the Diwwān al-Ṣabāba, which is a work that collects a lot of prominent men who felt a passionate love, and includes [in it] his modern and ancient words, both in verse and in prose ... [the Dìwān al-Ṣabāba] was discussed in the majlis of the sultan [Muhammad v] ... who paid attention to it-May God keep him-and found it good ... and he suggested me to compose [a similar work] on [passionate love] and wine ... but, how could the earth touch the sky, or compare East with

\footnotetext{
11 For the biography of Ibn Abī Ḥajala, see Ibn Ḥajar, Inb $\bar{a}$ i, 107-10; Ibn al-Imād, Shadharāt vi, 444-5; Gruendler, Ibn Abī Hajala (1325-75), 118-26.

12 For a general perspective of the political events of this Mamluk period, see Irwin, Middle, 125-51; Van Steenbergen, Order.

13 As we shall see, Ibn al-Khațīb, in his introduction to his work al-Rawdat al-ta' rïf, 8o-7, tells us that he was encouraged to write this work by Sultan Muhammad v, while in a letter sent to Ibn Khaldūn in the year $768 / 1367$, he tells us that it was his friends and colleagues who encouraged him to this task.

Ibn al-Khațîb, Rawda, 8o-3.
} 
the West? What a difference there is between an Oriental and a Western! ... [I]t occurred to me to take this love along the path that leads to eternity, the one that leads to the summit of happiness through the ascension stairs ... [that is] the love of God, the one that takes [you] near him.

Ibn al-Khațīb repeats this idea in some verses he dedicated to Ibn Abī Ḥajala: ${ }^{15}$

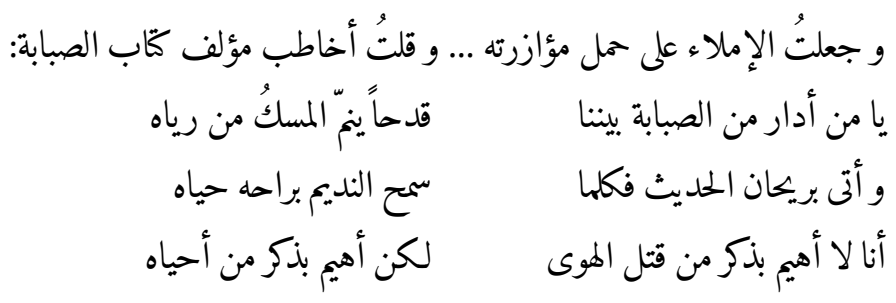

I started writing to answer [D̄wān al-șabāba] ... and I said when I wrote to its author:

1) Oh who with his $[D \bar{w} w \bar{a} n]$ al-șabāba made the cups circulate between us, while the fragrance of his musk expands.

2) He brought the myrtle (al-rayhān) of the conversation, and each time

allows the diner to rest, vivifies it.

3) I am not willing to mention those whom passion killed, But I want to remember those who [the passion] resurrected.

As soon as Ibn al-Khațîb completed his Rawdat al-ta'rîf, he sent a letter dated December 25, 1367 to Ibn Khaldūn, who was at that time in Tlemcen, in which he informed his friend that he had sent a copy of the Rawdat to the Sufi Khanqah of Sa'îd al-Su'adā'jl in Cairo that was led by Ibn Abī Ḥajala. He actually explained that he had sent it together with a copy of another of his works, his biographical dictionary of famous Granadian notables and scholars ( $a$ l-Ih $h \bar{a} t a f i$ $a k h b \bar{a} r$ Gharnāta) as well as with other works of his, the titles of which remain unspecified. ${ }^{17}$ According to the letter, Ibn al-Khațīb already knew that his works were having some impact:

\footnotetext{
15 Ibn al-Khațīb, Raw d̦a, 86.

16 About this hermitage, see al-Maqrīz̄, al-Mawā $i z$ 282-5.

17 The letter was preserved by Ibn al-Khaldūn, Riḥlat 111-2.
} 


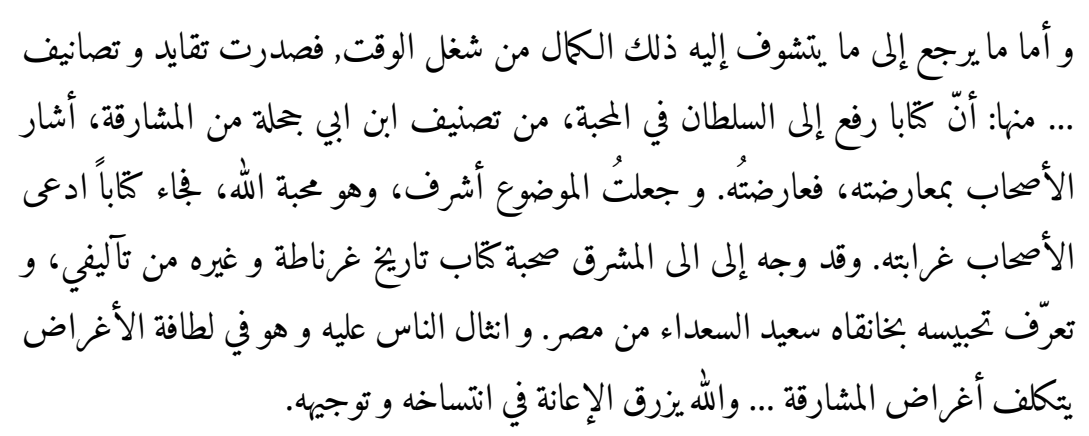

And as regards what you [perfection] would like [to know] about my occupations during my [free] time: some notes and works have arrived ... among them: a book about love has been sent to the sultan [Muhammad v], composed of Ibn Abī Hajala, an oriental. Some colleagues have suggested that I give him a reply and that's what I did. I made the subject nobler, the love of God. It is a work that colleagues have considered strange. It has been sent to the East together with the [Kitāb] Tärīkh Gharnāta and other of my works. When it became known that [those books] were available as an endowment in the Khanqah of Sa'̄ì al-Su'adā' in Egypt, the people have gone in great numbers [to consult it], since [it contains] subtleties that resemble those of the Orientals ... may God help me to make a copy and send [it to you].

The availability of such works in the Khanqah ${ }^{18}$ was decisive for their diffusion among Mamluk scholars. Ibn Abī Hajala, moreover, had been very positive in his reception of the Rawdat al-ta'riff, especially because he found in that work strong criticism of a group of Sufis who professed the doctrine of the unity of being (waḥdat al-wujūd), such as al-Shushtarī, Ibn Sabīn, Ibn Hūd, Ibn Aḥlā, Ibn al-Fāriḍ, and Ibn 'Arabī_all of whom Ibn Abi Hajala considered to be heretics. ${ }^{19}$ Thus, Ibn Abī Hajala mentions Ibn al-Khațīb in his work Ṣarāih alnașa $\bar{a}^{3},{ }^{20}$ a compendium of accusatory fatwās that formed the final part of his Dīwān Ghayth al-'āriḍ fı mu'äraḍat Ibn al-Färiḍ, specifically in the advice $\mathrm{n}^{\mathbf{0}} 14$ where he says:

\footnotetext{
18 See, for the Khānqāh institution in the Mamluk Period, Homerin, Saving 59-83; Fernandes, Evolution 96-113; Fernandes, Mamluk 87-98; Hofer, Popularization.

19 In relation to this orthodox criticism in Ibn al-Khațīb's works and its use by Ibn Abī Ḥajala, see Knysh, Ibn 'Arabi 172-84.

$20 \quad$ Ibn Abī Ḥajala, Șarāì 41.
} 


$$
\begin{aligned}
& \text { قال الشيخ العلامة المفتّن ذو الوزارتين لسان الدين أبو عبد الله محمد بن الخطيب ... في كتابه }
\end{aligned}
$$

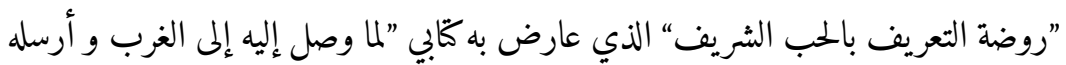

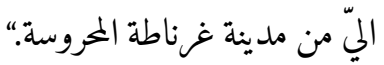

The shaykh, the imam, the erudite, the ingenious, and the possessor of the double vizierate, Lisān al-Dīn Abū 'Abdallāh Muḥammad b. al-Khațīb ... said in his work Rawdat al-ta'rîf bi-l-hubb al-shariff, with which he gave a reply to my work al-Dīwān al-șabāba, when it came to the West and then he sent me [his work] from the protected city of Granada.

And later on in the same work, ${ }^{21}$ Ibn Abì Ḥajala says in relation to Ibn Sabiin:

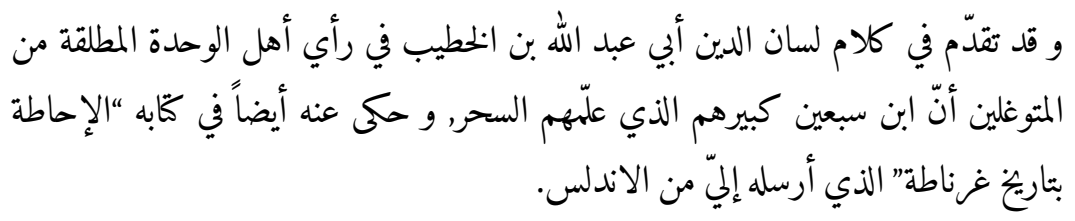

And we have already mentioned the words of Lisān al-Dīn Abī 'Abdallāh b. al-Khațīb about his opinion of those who have entered into the doctrine of absolute unity, [and that is] that Ibn Sabin is the worst of them, the one who taught them magic, and spoke of him [Ibn al-Khatiib] also in his book al-Ihāta bi-ta'īkh Gharnāta, which he sent me from alAndalus.

From this testimony, it seems that Ibn al-Khațib possibly sent a personal copy of his works to Ibn Abī Hajala, in addition to those he sent as a pious legacy to Sa'î̀ al-Su'adā', but we still do not have proof of this.

When Ibn Abī Ḥajala received the work of Ibn al-Khațīb, it is likely, as suggested by Emil Homerin, that he composed some verses in gratitude and praise of Ibn al-Khatịb's work in response to the verses that his Granadian colleague had included in the Rawda: "I sincerely love every Sufi, / and I am attuned to every lover / Yet I knew no station in love /until Instruction on noble Love (al-Ta'rîf bi l-hubb al-sharīf) arrived."22

\footnotetext{
21 Ibn Abī Hajala, Șarāìn al-nașāìn 72.

22 See the complete translation in Homerin, Ibn Abī Ḥağalah 25-6; Ibn Abī Ḥajala, Dīwān 188.
} 
Similarly, in the Dēwān of Ibn Abī Hajala, another poem is collected in honor of Ibn al-Khațîb. ${ }^{23}$

Another important work of Ibn Abì Hajala that testifies to this relationship between the two scholars is his Manțiq al-țayr, ${ }^{24}$ in which Ibn Abī Hajala quotes Ibn al-Khațīb several times. In one of the maqāmas (al-Maqāma al-Kutubiyya), recently studied by Maurice A. Pomerantz, ${ }^{25} \mathrm{Ibn}$ Abī Hajala laments the decline of the Cairo book market and how this problem needed to be solved. According to him, important books such as Kunāsat al-dukkān or al-Lamha al-badriyya fi-l-dawla al-nașriyya, both by Ibn al-Khațīb, were necessary for an adequate intellectual formation. ${ }^{26}$

In the same work, ${ }^{27}$ Ibn Abī Ỵajala describes his own work Șarāỉh al-nașä̉ih, commenting that after the 19 advices, it ends with the biography of nine characters who "spread corruption through Earth and were not virtuous." He is referring among them to al-Shushtarī, a disciple of Ibn Sabīn, whom Ibn alKhațīb, in the words of Ibn Abī Hajala, biographed without any reprehensible comment in the Ihạta while criticizing him more openly in the Rawdat:

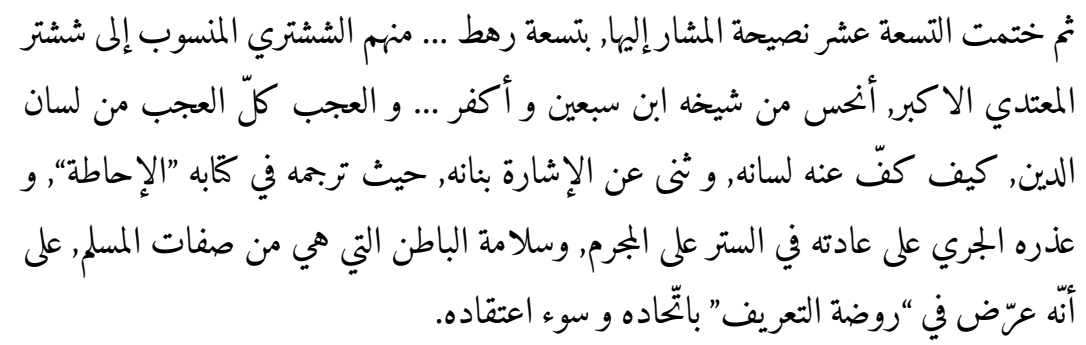

And then I concluded the 19 referred advices with the [reference] to nine characters ["that spread corruption through Earth and were not virtuous"], among them was al-Shushtarī, originally from Shushtar, the greatest of the transgressors, most fatal and more apostate than his master Ibn Sabīn ... and the most surprising thing about Lisān al-Dīn [Ibn al-Khațîb], is how he avoided speaking bad of him and did not point him with the finger when he presented his biography in his work al-Ihăța, and his fault, according to his custom, is the fact to cover up the criminal and

\footnotetext{
23 Ibn Abī Hajala, Dīwān 74-5.

24 This work has recently been edited by Aḥmad 'Abd al-Karīm al-Mashhadānī.

25 Pomerantz, Maqāmah 179-207.

26 Ibn Abī Hajala, Manțiq 264.

27 Ibn Abī Hajala, Manțiq 3o2. The letter is also collected by professor Hayat Qara on page 4 of her edition of Ibn al-Khațīb's work entitled Muqni'a al-sā’il 'an al-marạ̣ al-hä̉il.
} 
preserve the esoteric, which is one of the characteristics of the Muslim; however, he criticized him in his [work] Rawdat al-ta'rïf due to his unicity and his wrong judgment.

As we have seen, despite the admiration that the Tlemecene felt for Ibn alKhațīb, Ibn Abī Hajala did not hesitate to criticize him for his permissive and condescending attitude toward some of these heterodox Sufis in his famous work al-Ihāta bi-akhbār Gharnāṭa .

Finally, in Manțiq al-țayr, Ibn Abī Ḥajala inserted an important fragment of a letter sent to Ibn al-Khațīb: ${ }^{28}$

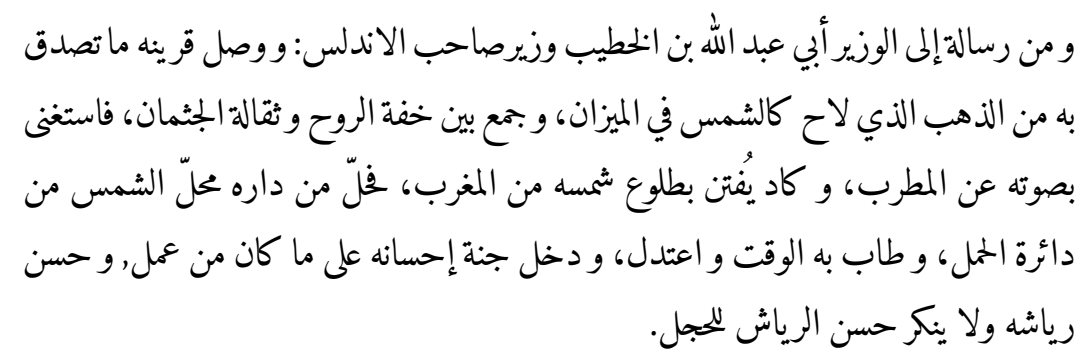

From a letter sent to the vizier Abū 'Abdallāh b. al-Khațīb, vizier of the lord of al-Andalus: And has reached to his partner the gold that justify [his fame], which shines like the sun when it is in the constellation of Libra and which gather sympathy and seriousness. He has to resign himself to dispense with the charm of his voice and is about to get excited when his sun rises in the west. He occupies in his country the same place that occupies the sun of the constellation of Aries. With him the time has been good and righteous, he entered the garden of goodness for his works, and he enjoyed a comfortable life [in the same way that] one cannot deny the beauty of the feathers of the partridge (hajala).

There was reciprocity in the admiration between these two scholars. In the first part of Ibn al-Khațīb's work, entitled Kitāb A'māl al-a lām, dedicated to the Muslim dynasties of the East, the Granadian scholar used various works by Mamluk authors as sources of information, especially from the Fatimid, Ayyubid, and Mamluk periods. Besides mentioning the works of Ibn Kathīr, al-Bidāya wa-l-nihāya, al-Dhahabī, Tārīkh al-islām, Ibn Khallikān, Wafayāt ala'yān, and Abū Shāma, Kitāb al-Rawdatayn - we do not yet know if Ibn al- 
Khațīb handled these sources directly—the most mentioned work is Sukkardān al-sulțān by Ibn Abī Ḥajala, which Ibn al-Khațīb considered the best source from the Mamluk period, especially during the three reigns of the Mamluk sultan al-Malik al-Nāṣir. ${ }^{29}$ It seems that Ibn al-Khațīb received his copy of the Sukkardān al-sulțān directly from Ibn Abì Hajala because when he mentions the reign of the first Ayyubid ruler of Egypt, Asad al-Dīn Shirkūh, he says: ${ }^{30}$

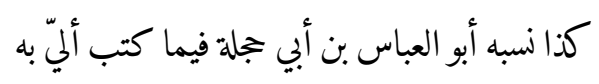

And thus was recorded his nasab by Abū l-'Abbās b. Abī Ḥajala according to what he wrote to me.

\section{Taking Advantage of Diplomatic Relations}

In the first part of Kitāb A'māl al-alām, Ibn al-Khațîb informs us of another important channel for the spread of his works: In addition to the direct delivery of his works to fellow scholars such as Ibn Khaldūn (d. 808/1406), Ibn Riḍwān (d. 781/1380 or 783/1382), Ibn Khātima (d. 77o/1369), and al-Sharīf al-Tilimsānī (d. $770 / 1369$ or $771 / 1370$ ), Ibn al-Khațib sent copies of his works to Muslim rulers, regents, and viziers due to his intense diplomatic activity. This we know through four letters in which the sending of such books is mentioned:

1. One letter, undated, was sent to Yalbulghā al-Khāșșakī (d. $767 / 1366),{ }^{31}$ regent of the Mamluk sultan minor Shabān b. Ḥusayn (r. 764-78/1363$\left.{ }_{76}\right)^{32}$ in which the Granadian author refers to the sending of some of his works without specifying which ones.

2. Another letter, ${ }^{33}$ undated, was sent to the supreme $q \bar{a} d \bar{\imath}$ of Egypt, Abū lBaqā' al-Subkī, which specifies that the Andalusi vizier sent some of his works to the Mamluk sultan. Ibn al-Khațîb included the response letter ${ }^{34}$

29 The explicit references to the work of Ibn Abī Ḥajala are a total of 16. See Ibn al-Khațîb, A'māl 96, 203, 228, 239, 259, 279, 283, 288, 29o, 291, 292, 296, 309, 311, 312, 313, 315, 316, 317, 318, 319 .

$30 \quad$ Ibn al-Khațīb, $A^{\text {‘́măl } 259 .}$

31 In relation to this Mamluk political figure, see Van Steenbergen, Brink 117-52; Van Steenbergen, Amir 423-43.

32 Ibn al-Khațīb, $A^{\prime} m \bar{a} l$ 321; Rayḥ̄nat i, 587; Al-Qalqashandī, Subḥ i, 64-7.

33 Ibn al-Khațīb, $A^{\prime} m a \bar{a} l$ 323; Rayhạnat ii, 164-7.

34 This letter was written by the secretary (kātib) Șālị̣ b. Aḥmad b. Muḥammad al-Amawī on Muḥarram 23, 768/September 29, 1366. Ibn al-Khațīb, Ámāl 326. 
in which the $q \bar{a} d \bar{\imath}$ refers to the fact that the sultan read Ibn al-Khațîb's Kitāb al-Ihạța fi tārīkh Gharnāta and:

$$
\begin{aligned}
& \text { و وقف المملوك أيضاً من تصانيفه الشريفة على "كّاب الإحاطة في تاريخ غرناطة،، فوجدة }
\end{aligned}
$$

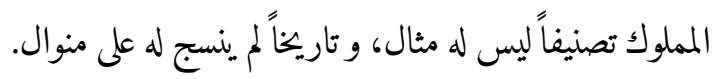

The humble servant (mamlūk) read from his noble works the Kitāb alI hạata fi tārīkh Gharnātạ, and found it a work without equal and an inimitable chronicle.

3. A letter sent to the amir of Mecca. ${ }^{35}$

4. A letter sent to the amir of Medina ${ }^{36}$ in which Ibn al-Khațib says that he has sent to this amir, in addition to the letter, a treatise (risāla) and a qasida in honor of the tomb of the Prophet. Ihăța in Cairo

As we have said, Ibn al-Khațîb also sent in his life a copy of his biographical dictionary al-Ihạțta fì akhbār Gharnāța to the Khanqah Sa'ìd al-Su'adā'. This copy was used by many Mamluk scholars as well as Maghrebis who traveled to the East.

The manuscript was described by 'Abdallāh 'Inān in his introduction to his edition of the Ihăta $a,{ }^{37}$ where he tells us:

$$
\begin{aligned}
& \text { ويجد بمكتبة رواق المغاربة بالأزهار، بمجوعة خطية، من اوراق متناثرة من كتاب الإحاطة، }
\end{aligned}
$$

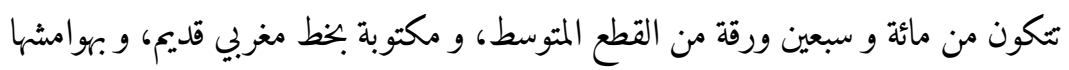

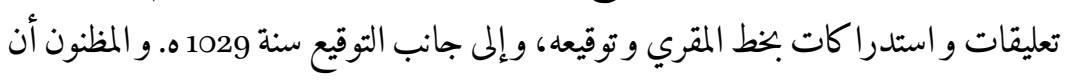

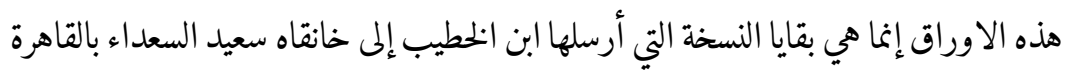

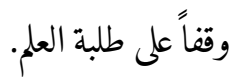

35 Ibn al-Khațīb, Ámāl 343; Rayḥ̄nat i, 206-12; al-Qalqashandī, Subh vii, 47-53.

36 Ibn al-Khațîb, A'māl, 344; Rayḥ̄anat i, 213-5.

37 Ibn al-Khațîb, al-Ihạața $i,{ }_{15}^{-6 .}$ 
In the Library of the Riwāq al-Maghāriba (The Gallery of the Maghreb), in the Al-Azhar Mosque, there is a collection of scattered and handwritten sheets of the Ihäta: There are 170 medium-sized folios written in an ancient Maghrebi handwriting, on whose margins are notes and signed comments by al-Maqqarī dated in 1029/162o. It is thought that these sheets are the remains of the manuscript copy that Ibn al-Khatịb sent to the hermitage of Sa'îd al-Su'adā' in Cairo as a pious endowment for the students.

To date, we do not know the whereabouts of this copy. We only have information that the Library of the Riwāq al-Maghäriba holds a recent copy of the I Ihāta (manuscript $\mathrm{n}^{\circ} 36146$, date $1314 / 1898$ ) from the 19th century that was made directly from the handwritten copy of Ibn al-Khațib in order to preserve the original manuscript from further deterioration.

Although authors like Ibn Ḥajar, al-Sakhawī, and al-Suyuṭī used this copy extensively, ${ }^{38}$ the famous scholar of Tlemecen, al-Maqqarī, is the main figure to know this manuscript and the use made by the contemporary and later Mamluk authors of Ibn al-Khațîb.

Al-Maqqarī (984-1041/1577-1632) records ${ }^{39}$ that the eldest son of Ibn alKhațîb handled this copy in Cairo: ${ }^{40}$

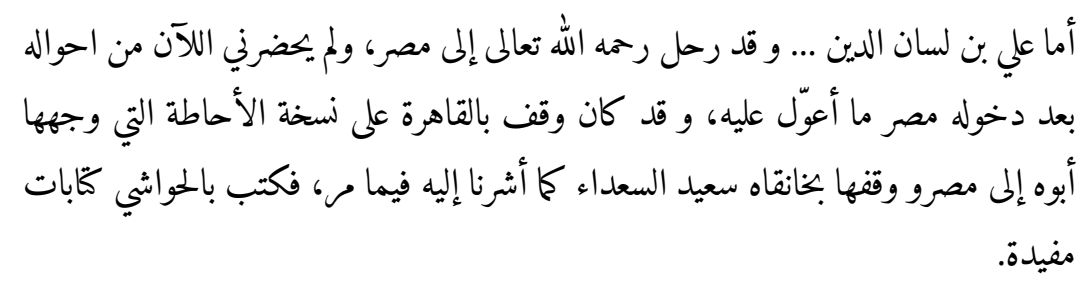

'Alī b. Lisān al-Dīn ... traveled—God the highest have mercy on himto Egypt, and I do not find now accurate information about his situation after entering Egypt. He handled and read in Cairo the copy of the Ihātta that his father had sent to Egypt as an endowment (waqf) in the Khanqah of Sa'īd al-Su'adā', as we have indicated above. He wrote useful annotations in its margins.

38 See Rosenthal, History 472.

39 Some of the passages that we will see below have been studied by Velázquez Basanta, Nota 264-85.

$40 \quad$ Al-Maqqarī, Naf̣̣ vii, 301. 
Previously he had explained that: ${ }^{41}$

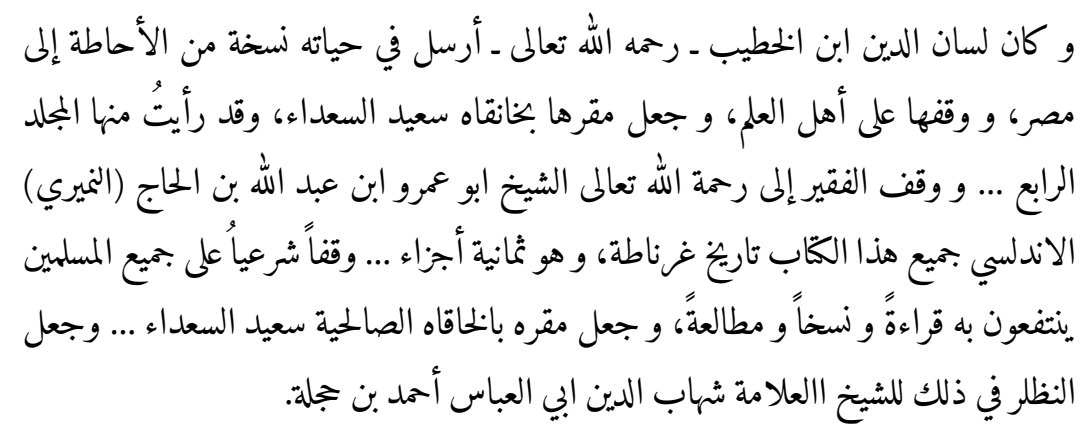

Lisān al-Dīn b. al-Khațîb-God the highest have mercy on him-sent a copy of the Ihāta to Egypt in life to be deposited as pious endowment for the people of science, at the Khanqah of Sa'ìd al-Su'adā', and I have seen the fourth volume ... and this pious endowment was established by the Shaykh who asks for the mercy of God the highest, Abū 'Amr b. 'Abdallāh b. al-Hāijj (al-Numayrī) al-Andalusī of all this book [entitled] History of Granada which has eight parts ... as a legal pious endowment for all Muslims to take advantage of it for reading, copying or studying, and deposited it in the pious Khanqah of Sa'īd al-Su'adā' ... and gave its supervision to the wise Sheikh Shihāb al-Dīn b. al-'Abbās Aḥmad b. Ḥajala.

Ibn Khaldūn, ${ }^{42}$ who had settled in Cairo in the year $784 / 1382$, made ample use of this copy and was also influential in making Ibn al-Khațîb's works known. Through the correspondence between the two, we know that Ibn al-Khatịb had sent several copies of his works to the Tunisian when the latter was in the Maghreb. ${ }^{43}$ Ibn Khaldūn seems to have taken them with him to Cairo and used them in his teachings in this city where he had among his students al-Maqrīzì and Ibn Ḥajar. ${ }^{44}$ Al-Maqqarī furthermore records that al-Ba'ūnī (d. 868/1464), a Syrian disciple of Ibn Khaldūn, studied with him the works of Ibn al-Khațîb:45

\footnotetext{
41 Al-Maqqarī, Naf̣ vii, 105-6.

42 For a general approach to the life and works of Ibn Khaldūn, see Manzano Rodríguez, Ibn Jaldūn 578-97; Fischel, Ibn Khaldūn; Talbi, Ibn Haldūn 6-25.

43 See Ibn Khaldūn, Rihla 111-2, 116-8.

44 Despite the numerous studies dedicated to the personal and professional relationship between Ibn al-Khațīb and Ibn Khaldūn, a deeper analysis of the possible influence of the work of the Granada vizier in the Kitāb al-ibar of the Tunisian author is still pending. Al-Maqqarī, Nafḥ vi, 192.
} 
لقد رأيت بخطّ العالم الشهير الشيخ ابراهيم الباعوني الشامي فيما يتعلق بابن خلدون ... في سنة

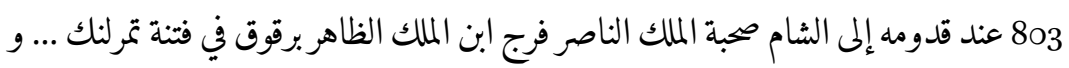

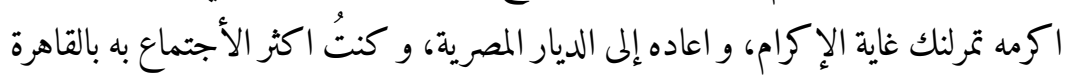

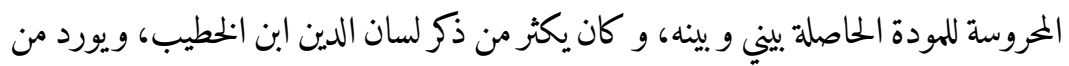

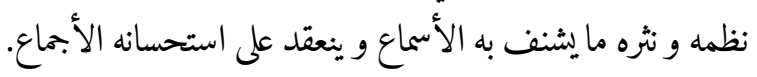

And I saw (al-Maqqarī is speaking) written by the hand of the famous and wise Syrian Shaykh Ibrāhīm al-Ba'ūnī, in relation to Ibn Khaldūn ... in the year 803/140o, when he arrived in Syria accompanied by al-Malik alNāṣir Faraj b. al-Malik al-Ẓahir Barqūq during the troubels of Timur Lank ... Timur Lank greatly honored [Ibn Khaldūn] and allowed him to return to Egypt. Then I used to meet him in the protected city of Cairo thanks to the great affection that existed between us two. He often mentioned Lisān al-Dīn b. al-Khațīb (in his classes), and quoted from his poetry and his prose what ecstatic the ears and everyone likes about it.

Among many of the Mamluk scholars who made use of the copy of the Ihāta available in Cairo, Badr al-Dīn al-Bishtakīi6 (d. 830/1426-7), a student of Ibn Khaldūn, Ibn Ḥajar, and Ibn Abī Ḥajala, made a compendium entitled Markaz al-Ihăța bi-udabā’ Gharnāta of which there are currently five manuscripts: Berlin, Paris, Manchester, Leipzig, and Cambridge. ${ }^{47} \mathrm{Al}$-Maqqarī knew of this compendium ${ }^{48}$ and told us about it:

$$
\begin{aligned}
& \text { أما كَاب الأحاطة فهو الطائر الصيت بالمشرق والمغرب، والمشارقة أشدّ إعجاباً به من المغاربة، }
\end{aligned}
$$

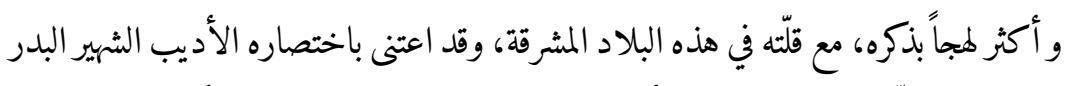

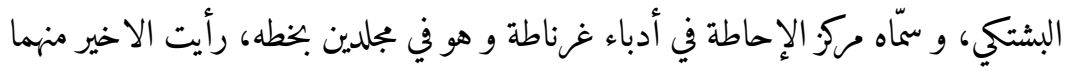

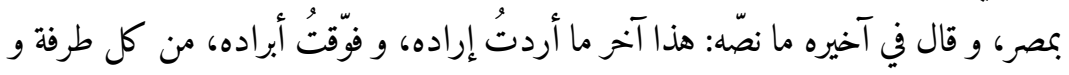

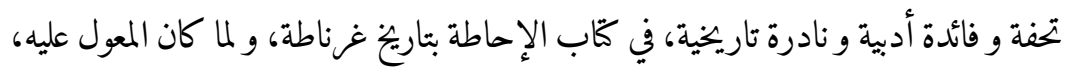

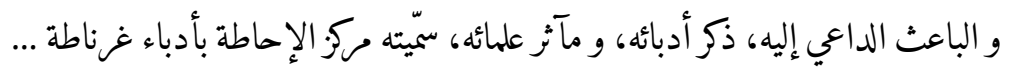

46 See Ibn Ḥajar, Inbā' iii, 392-3; Ibn al-Imād, Shadharāt ix, 282-3; Al-Sakhāwī, al-Daw' v, 277-9.

47 See Bourhalla, El Markaz 17-25.

48 Al-Maqqarī, Naf̣ vi, 88. 


\section{و قد جعل كل أربعة أجزاء من الأصل في مجلّد، إذ هو في مجلدين كما سبق، و نسخة الأصل \\ في مثانية مجلدات، فنقص من الأصل ثلاثة أرباع أو أكثر.}

As regards the book of the Ihat ta, it is the bird whose fame is known in both the East and the West, and the Orientals admire it more than Westerners, and cite it to a greater extent, despite the scarcity [of information it contains] about the East. And the famous literary man al-Badr al-Bishtaki summarized it and called it Markaz al-Ihăța bi-udabä' Gharnāta, in two volumes in his own handwriting, the second of which I have seen in Egypt, and he said at the end of the same: This is the end of what I wanted to record, listing their robes with every novelty, gift and literary usefulness, [with every] historical anecdote that exists in the book al-Ihāta bi-ta'rikkh Gharna $\bar{t} a$, and since its purpose and main intention is the mention of its literari and the deeds of its sages, I have called it Markaz al-Ihăța bi udaba $\bar{a}^{2}$ Gharnāța ...

And he made one volume out of the four volumes of the original, and it consists of two volumes, as has been said, since the original copy was eight volumes, thus reducing the original in three quarters or more.

The manuscript of the Markaz that exists in Paris (Arabe 3347) includes part of the ijāza that Ibn al-Khaldūn granted to al-Bishtakī and in which the transmission of a celebrated epistle of Ibn al-Khațīb entitled Iftirās al-ișāba ilä iftirāsh al-ināb $a^{49}$ addressed to the Hafsid sultan of Tunisia is mentioned:50

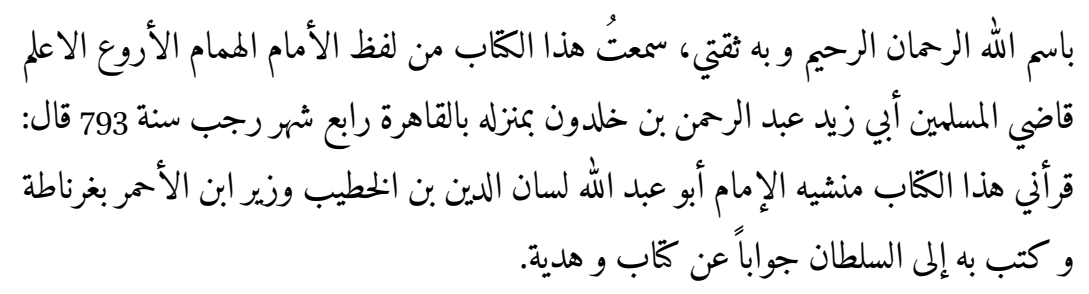

In the name of God, Compasive and Merciful, my trust is placed in him, I heard this letter from the magnanimous splendid and wise Imam, the $q \bar{a} \mathfrak{d} \bar{\imath}$ of the Muslims Abū Zayd 'Abd al-Rahmān b. Khaldūn in his house in Cairo on the fourth day of the month of rajab in the year 793/139o and said: This letter was read to me by its author, the Imam Abu 'Abdallāh

The text is at the end of the manuscript, on sheet 276 . 
Lisān al-Dīn b. al-Khațīb, vizier of Ibn al-Aḥmar in Granada and wrote it to the sultan [of Tunisia], in response to a letter from him and a gift [previous].

On his part, al-Maqqarī used the copy of the Ihạța available in Cairo to write his works Nafh al-țīb and Azhār al-riyād. He also made additions and commentaries to the manuscript, ${ }^{51}$ as those who had handled it before had also done, among them 'Alī b. al-Khațīb and the Maghrebi Ibn Marzūq. Ibn Marzūq made additions to his own biography included in the Ihâta, additions that were collected by Ibn Hajar al-'Asqalani ${ }^{52}$ and al-Sakhawi ${ }^{-53}$ in their respective biographies dedicated to Ibn Marzūq.

Finally, al-Maqqarī informs us ${ }^{54}$ of the handling of this work by several Mamluk and Western authors who traveled to Cairo, some of whom left their signature on the manuscript when they consulted it in the hermitage of Saild al-Su'adā':55

$$
\begin{aligned}
& \text { وقد رأيت بظهر أولّ ورقة من هذه النسخة خطوط جماعة من العلماء6 فن ذلك ما كتبه }
\end{aligned}
$$

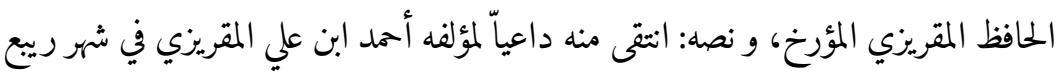

$$
\begin{aligned}
& \text { سنة مثان و ثمانمائة. } \\
& \text { و ما رقه السيوطي و نصه: الحمد لله وحده، و طالعته على طبقات النحاة و للغويين، و كتبه } \\
& \text { عبد الرحمن بن أبي بكر السيوطي سنة مُمان و ستين و ثمانمائة. }
\end{aligned}
$$

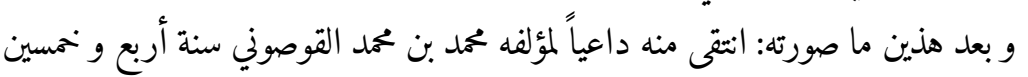

$$
\begin{aligned}
& \text { تسعمائة. }
\end{aligned}
$$

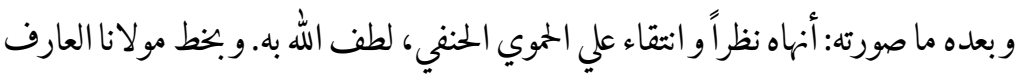

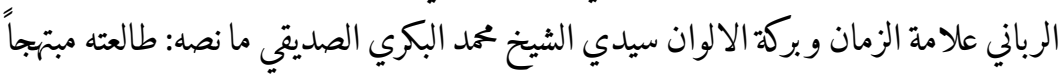

$$
\begin{aligned}
& \text { برياضه المونقة، و ازهار معانيه المشرقة، مرتقياً في درج كلماته العذاب سماء الاقتباس، مقتنياً } \\
& \text { من لطائفه درراً و جواهر بل أحاشيها بذلك القياس، كتبه محد الصديقي غفر الله له؛ إنتهى. }
\end{aligned}
$$

$5^{1} \quad$ The study of all these additions and annotations is being analyzed in my current research carried out within the AMOI project (Local contexts and global dynamics: al-Andalus and the Maghreb in the East), directed by Maribel Fierro and Mayte Penelas.

52 Ibn Hajar, al-Durar v, 93-7.

53 Al-Sakhawī, al-Tuhfa iii, 506.

54 Al-Maqqarī, Naf̣ vii, 106.

55 Velázquez, Basanta, Nota 279-80. 
And I have seen on the back of the first page of this copy, the texts of a group of scholars, such as what the hăfiz and historian al-Maqrīzì wrote, whose text is: he selected from it, asking [from God] by its author, Ahmad b. 'Alī al-Maqrīīi in the month of $r a b \bar{\imath}$ of the year 808/August 27 to October 24,1405 .

And what the hâfiz al-Suyūṭi wrote, whose text is: Praise be to God, the One! I read the categories of grammarians and philologists, and it was written by 'Abd al-Raḥmān b. Abī Bakr al-Suyūṭī, the year 868/1463-4. End.

And after these two, there comes something that would be: He selected from it, begging [God] for his author, Muhammad b. Muhammad alQawșūnī, the year 954/1547-8.

And then, something that would be: He finished the examination and selection of it 'Alī al-Ḥamawī al-Ḥanafì, God's goodness be with him!

And from the hand of our lord, the wise master of the era and blessing of time, my lord Shaykh Muhammad al-Bakrī al-Ṣadīqī, whose text is: I read it excited for its elegant gardens and flowers of bright meanings, ascending by the steps of his sweet words to the sky of the literary loan and acquiring of his kindness pearls and precious stones that he cannot avoid imitating. Muhammad al-Ṣiddīqī wrote it, God forgive him! End.

Al-Maqqarī also mentioned that he saw:

$$
\begin{aligned}
& \text { و رأيتُ بهامش هذه النسخة كتابة جماعة من أهل المشرق و المغرب كابن دقاق و الحافظ ابن }
\end{aligned}
$$

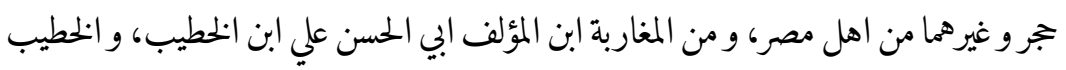

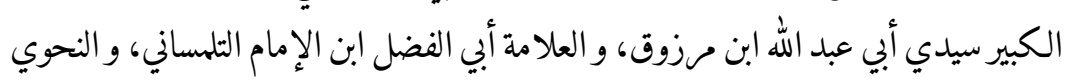

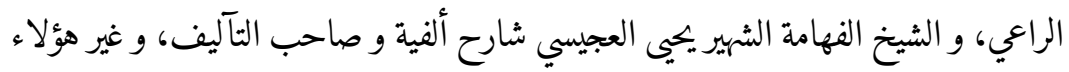

$$
\begin{aligned}
& \text { من يطول تعدادهم، رحم الله تعالى جميعهم. }
\end{aligned}
$$

And I have seen in a note on the margin of this copy the signature of a group of Orientals and Westerners, such as Ibn Duqmāq; the hāfiz Ibn Hajar, and others of the people of Egypt; and among Westerners, the author's son, Abū l-Hasan 'Alī b. al-Khațīb, the great preacher and my lord Abū 'Abdallāh b. Marzūq; the sage Abū l-Faḍl Ibn al-Imam al-Tilimsānī; the grammarian [Abū 'Abdallāh Muhammad] al-Rầ'̄, the famous and smart Shaykh Yahya al-Aȳisī, commentator of the Alfiyya and author of [other] works, as well as others that would be lengthy to tell, mercy on them all! 
In the absence of a more in-depth study of the exact use that Mamluk authors gave to the works of Ibn al-Khațîb, not only the Ihāta following list a general overview of the Mamluk authors who directly handled the copy of the Cairo Ihâta by Ibn al-Khațib (and in some cases also two other works, the Rayhānat al-kuttāb and the Rawdat al-ta'rîf):

1. Ibn Abī Ḥajala (d. 776/1375): Manțiq al-tayr and Șarāiḥ al-nașāàh ${ }^{56}$

2. Ibn Farḥūn (d. 799/1397): Dībājal-mudhab ${ }^{57}$

3. Ibn Ḥajar al-'Asqalānī (d. 852/1449): al-Durar al-Kāmina, ${ }^{58}$ Inbāa alGhumr, ${ }^{59}$ and al-Majma' al-mu'assis ${ }^{60}$

4. Ibn Duqmāq61 (d. 809/1407): ¿ ?

5. Ibn Hijja al-Ḥamawī (d. 837/1434): Jizānat al-adab, ${ }^{62}$ Thamarāt alawrāq, ${ }^{63}$ Qahwat al-insh $\bar{a}^{3},{ }^{64}$ and Kashf al-lithām ${ }^{65}$

6. al-Qalqashandī (d. 820/1418): Șubh al-a sha $\bar{a}^{66}$

7. al-Maqrīīì (d. 845/1442): al-Muqaffā l-kabīr, ${ }^{67}$ Durar al-uqūd, ${ }^{68}$ and alSulūk li-ma'rifa duwal al-mulūk69

8. Badr al-Dīn al-Bishtakī (d. 829/1426-7): Markaz al-Ihātạta bi udabä’ Ghar$n \bar{a} t a^{70}$

9. Ibn Tagrīibirdī (d. 874/1470): al-Manhal al-șā fì $\overline{i n}^{71}$

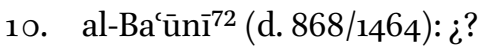

11. al-Sakhawī (d. go1/1496): al-Tuhfa al-lațîfa, al-Daw' al-lāmi', and Wajizz alkalām fì dhayl 'alā duwal al-islām ${ }^{73}$

$5^{6} \quad$ We can see the use of the Ibn al-Khațîb's works by this author in the texts quoted above.

57 See Ibn Farhūun, Dībāj i, 187,188, 398; ii, 57, 71, 111, 119, 121, 264.

58 See, for instance, Ibn Hajar, al-Durar i, 94-5; v, 219.

59 See Ibn Hiajar, Inb $\bar{a}^{`}$ i, 91-3, 206-7.

6o See Ibn Ḥajar, al-Majma ii, 436, 628, 636-7; iii, 16o, 310.

61 We know, as we have seen thanks to al-Maqqarī, that this author used the manuscript of the Ihăta located in Cairo in his works, but we still do not know in which of them he made this use. Probably it was in his, now lost, history.

62 See Ibn Hijja, Jizānat i, 33, 35, 81, 112; ii, 241.

63 See Ibn Hijja, Thamarāt ii, 127, 130.

64 See Ibn Hijja, Qahwat 347-8, 406-8.

65 See Ibn Hijja, Kashf 153 .

66 See, for instance, al-Qalqashandī, Șubḥ i, 129; vi, 458, 535; vii, 5o, 61, 64, 67, 70, 74.

67 See al-Maqrīzì, al-Muqaffā ii, 66.

68 See al-Maqrīzī, Durar iii, 443-8.

69 See al-Maqrīzī, al-Sulūk iv, 264; vi, 28o.

70 See what we have said above about al-Bishtakīs work, a resume of Ibn al-Khațîb's al-Ihāạta.

71 Ibn Tagrīibirdī, al-Manhal iv, 10; v, 336-7.

72 Like Ibn Duqmāq we do not yet know in which work/s he made use of the works of Ibn al-Khațīb.

73 See the use of Ibn al-Khațîb's works by al-Sakhawī in Rosenthal, History $457-5$ o1. 
12. Ibn Qāḍī Shuhba (d. 851/1448): Tārīkh Ibn Qā dị Shuhba ${ }^{74}$

13. al-Suyūṭī (d. 910/1505): Bughyat al-wu'āt $t^{75}$

14. ¿Ibn Shāhīn (d. 919/1514): ¿Nayl al-amal fí dhayl al-duwal?76

\section{$5 \quad$ Conclusion}

In view of the above, we can extract two main ideas. The first is that the ambition and concern of the Granada vizier to make his works known in the East had the success that his author wanted. In my opinion, he had more success than he was aware of in his life because after his death in $776 / 1374$, the diffusion of his works increased until the second half of the 18th century. This need of Ibn al-Khațib to "internationalize" his intellectual production in those eastern territories was not accidental. To his personal and intellectual concerns to achieve this goal, two very important factors were added. The first was the high position he reached in the Nașrid court, first as secretary of Sultan Yūsuf I and his son Muhammad v, and then reaching full power as grand vizier of the latter. This circumstance evidently facilitated his international relations and contributed greatly to the sending of his works to the East. The second factor, closely linked to the first, is related to the political situation of the Nașrid kingdom. During the first century of the life of the Granada kingdom (from the second half of the 12th century until the first half of the 13th century), the latter had its sights set on the Western kingdoms, both Christian and North African, in such a way that one can speak in cultural terms of a "Westernization." However, from the second half of the 14th century until the end of the Islamic presence in the peninsula, which happened in 897/1492 with the delivery of the city of Granada, the growing and unstoppable Christian threat caused a withdrawal of the Nașrid amirate, which from that time put its sights on the East as a point of reference on which to rely. This led to a process of "Orientalization" and rejecting any Western influence, although in practice it could not avoid it completely. ${ }^{77}$ So, this preference for the Islamic kingdoms of the East, which were seen both politically and economically safer and more powerful, inevitably favored the spread of Ibn al-Khatib's works to those eastern territories.

74 See Ibn Qāḍī Shuhba, Tārīkh ii, 178, 439, 497-8, 701-3.

75 See in the text above al-Suyuțì's signature in the al-Ihāta copy of Cairo.

76 The use of the work of Ibn al-Khațīb by this author requires further analysis. For this reason it appears between question marks.

77 See the recent study about the relationship of the kingdom of Granada with the Mamluk sultanate of Egypt, coordinated by Calvo Capilla, Las artes. 
What I have presented here is part of a work in progress in which my aim is to document all the channels through which Ibn al-Khațib's work became known in the East. This is part of a larger project, of which I am a member, that studies how knowledge about the Maghreb became integrated into historical and other works by Mashriqi scholars (AMOI). Obviously, this is a very complex issue that requires the study and analysis of other ways of diffusion of Ibn al-Khațîb's work, such as the transmission through his numerous disciples, both in al-Andalus and in the Maghreb, who, when emigrating to the East, either to make the pilgrimage or because of their desire to settle there, took with them their iyāzas and fragments of the works of Ibn al-Khațīb. An example of this is the wise Meccan Taqī al-Dīn al-Fāsī (d. 832/1429) who made use in his Iḍahh bughyat alh al-bașāra fi dhayl al-Ishāra ${ }^{78}$ of the texts brought to the East by a disciple of Ibn al-Khațîb named al-Qāsim b. 'Alī al-Fāsī al-Tinmālī $\left(743^{-811} / 1342-1408\right),{ }^{79}$ who was born in Malaga.

In the specific case that I have presented here, Cairo and the presence of two Maghrebis - Ibn Abī Hajala and Ibn Khaldūn — who had settled there played a decisive role in constructing Ibn al-Khațîb's fame. Their training and their interests made them continue to look to the West. They corresponded with Maghrebis, including Ibn al-Khațib himself, and wanted to be kept informed of what was going on in the lands they had left. Ibn al-Khațib's role was nevertheless decisive: He took care of sending copies to Egypt through different channels and was undoubtedly aware that his works would provide scholars in the Mashriq with information that was needed on the history of al-Andalus. But he was also convinced of the high quality of his own production, an appraisal that appears to have been shared by those who read him.

Finally, we can say that the case of Ibn al-Khatịb is not an isolated one. The information provided by the Granadian vizier and many other Western authors about the history of the Western territories, through the diffusion of their works in the East, mainly during the 14 th and $15^{\text {th }}$ centuries, contributed to the molding of the imagination of the Western history produced by Eastern, mainly Mamluk, authors, who obtained their information by consulting all these Western works. A significant example is the aforementioned al-Maqqarī who supplied a Syrian audience, eager for news about the past of the West,

78 Al-Fāsī, I Ịāh 352, 353, 399, 425. I want to highlight here that Professor J. Zenka will soon publish a study about this scholar.

79 I am currently carrying out a study on the diffusion in the East of the work of Ibn al-Khațib through his disciples whose results I hope to publish soon. 
with all the Andalusian and Maghrebi legacy that he could carry with him on his trip to Egypt and Syria. The extent of this contribution is still difficult to measure. In the case of our author Ibn al-Khați b, it is necessary to know what texts from his works were adopted by the eastern authors who used his works as sources. This is a very interesting issue that will be the focus of our future research.

\section{Bibliography}

\section{Manuscripts}

al-Bishtak̄̄, Markaz al-Iḥāța bi udabā’ Gharnāța, Paris Manuscript, nº 3347 .

\section{Primary Sources}

Ibn Abī Ḥajala, Dīwān al-Ṣabāba, ed. M. Zaglūl Sallām, Alexandria 1987.

Ibn Abī Hajala, Sukkardān al-sulțān, ed. 'A.M. 'Umar, Cairo 2000.

Ibn Abī Hajala, Șarāih al-naṣāiḥ, ed. A.'A.'I 'A. al-Salafī al-Mutaṭabbib, Beirut 2003.

Ibn Abī Ḥajala, Manțiq al-țayr, ed. A.'A. al-Mashhadānī, Rabat 2018.

Ibn Abī Hajala, Dīwān Ibn Abì Hajala, ed. M.M. Bahjat and A.Ḥ. Mukhlif, Amman 2010. Ibn Farḥūn, Dībāj al-mudhab, ed. M. al-Aḥmadī, 2 vols., Cairo 2011.

Ibn Ḥajar al-'Asqalānī, al-Durar al-Kāmina fì a'yānn al-mỉa al-thāmina, ed. M.S. Jād alHaqq, 5 vols., Cairo 1966.

Ibn Ḥajar al-'Asqalānī, Inbā̄ al-Ghumr bi-anbā' al-'umr, ed. Ḥ. Ḥabashī, 4 vols., Cairo 1969.

Ibn Hiijja al-Ḥamawī, Kashf al-lithām, ed. M.S. al-Ansī, Beirut 1896.

Ibn Hijja al-Ḥamawī, Jizānat al-adab, ed. I. Shaqwī, 2 vols., Beirut 2004.

Ibn Hijja al-Hamawī, Qahwat al-Inshāe, ed. R. Pizzili, Beirut 2005.

Ibn Hijja al-Ḥamawī, Thamarāt al-awrāq, ed. M. Abū l-Faḍl Ibrāhīm, Beirut 2005.

Ibn al-'Imād, Shadharāt al-dhahab, ed. M.'A. 'Ațā, 9 vols., Beirut 1998.

Ibn Khaldūn, Rihlat Ibn Khaldūn (al-Tárīf), ed. M. b. Tāwīt al-Ṭanjī, Beirut 2009.

Ibn al-Khațīb, Raw dat al-ta'rīf bi-l-ḥubb al-sharīf, ed. M. al-Kattānī, 2 vols., Beirut 1970. Ibn al-Khațīb, al-Ihāạta fi akhbār Gharnāța, ed. M.'A 'Inān, 4 vols., Beirut 1973-7.

Ibn al-Khațīb, Rayḥānat al-kuttāb wa nuj'a al-muntāb, ed. M.'A. 'Inān, 2 vols., Cairo 1981. Ibn al-Khațīb, Kitāb A'māl al-a lām, ed. H..S. Kasrawī, Beirut 2003.

Ibn al-Khațīb, Muqni'a al-sā̉il 'an al-marạ̣ al-hä̉il, ed. H. Qara, Rabat 2015.

Ibn Qāọī Shuhba, Tārīkh Ibn Qāộ̄ Shuhba, 'A.D. Nashar, 2 vols., Damascus 1994.

Ibn Taghrībirdī, al-Manhal al-ṣāfì, ed. M.M. Amīn, 13 vols., Cairo 1984.

al-Maqqarī, Nafḥ al-țīb, ed. I. 'Abbās, 8 vols., Beirut 1968.

al-Maqrīzī, al-Mawā'iz wa-l-i'tibār bi-dhikr al-hițāțwa-l-āthār, ed. M. Zaynaham and M. al-Sharqāwī, 4 vols, Cairo 1997. 
al-Maqrīzì, al-Sulūk li- márifa duwal al-mulūk, ed. M.'A. 'Ațā, 8 vols., Beirut 1997 .

al-Maqrīzì, Durar al-'uqūd, ed. M. al-Jalīlī, 4 vols., Beirut 2002.

al-Maqrīzì, al-Muqaffā al-kabìr, ed. M. al-Ya'lawī, 8 vols. Beirut 2006.

al-Qalqashandī, Șubḥ al-a shā fí șinā'at al-inshä', ed. M.Q. al-Baqlī and S.'A 'Āshūr, 14 vols., Cairo 1985.

al-Sakhawī, al-Tuḥfa al-lațīfa, ed. A.Ṭ. al-Ḥusaynī, 3 vols., Cairo 1979.

al-Sakhāwī, al-Ḍaw’ al-lāmi li-ahl al-qarn al-tāsic, ed. Dar Maktabat al-Hayāt, 12 vols.,

Beirut n.d.

al-Suyūṭī, al-Fāriq bayna al-mușannif wa-l-sāriq, ed. H. Nājī, Beirut 1998.

Taqī al-Dīn al-Fāsī, Iṭāḥ bughyat alh al-baṣāra fì dhayl al-Ishāra, ed. A. 'Abd al-Satār, Cairo 2012.

\section{Secondary Sources}

Ballan, M. The scribe of the Alhambra: Lisān al-Dīn Ibn al-Khațīb, sovereignty and history in Nasrid Granada, PhD diss., University of Chicago 2019.

Bauden. F., Maqriziana Ix: Should al-Maqrīzī be thrown out with the bath water? The question of his plagiarism of al-Awḥadì's Khițațand the documentary evidence, in MSR 14 (2010), 159-232.

Binbas, I.E., Intelectual networks in Timurid Iran, Cambridge 2016.

Bourhalla, A., El Markaz al-Ihāța, un resumen inexplorado de la gran obra de Ibn alJaṭīb, in M.D. Rodríguez Gómez, A. Peláez Rovira and B. Boloix Gallardo (eds.), Saber y poder en al-Andalus: Ibn al-Jațīb (s. XIV), Cordoba 2014, 17-25

Calvo Capilla, S., Las artes en al-Andalus y Egipto: Contextos e intercambios, Madrid 2017.

Elger, R., Adab and historical memory. The Andalusian poet/politician Ibn al-Khațîb as presented in Aḥmad al-Maqqarī (986/1577-1041/1632), Nafḥ aṭ-țîb, in WI 42/3 (2002), 289-3o6.

Fernandes, L., Mamluk politics and education: The evidence from two fourteenth century waqfiyya, in $A I 23$ (1987), 87-98.

Fernandes, L., The evolution of a Sufi institution in Mamluk Egypt: The Khanqah, Berlin 1988.

Fischel, W.F., Ibn Khaldūn in Egypt (1382-1406). His public functions and historical research: An essay in Islamic historiography, Berkeley 1967.

Fromherz, A., Ibn Khaldūn, Ibn al-Khațīb and their milieu: A community of letters in the fourteenth-century Mediterranean, in Medieval encounters 20, 4/5 (2014), 288305 .

Gruendler, B., Ibn Abī Hajala (1325-75), in J.E. Lowry and D.J. Stewart (eds.), Essays in Arabic literary biography: 1350-1850, ii, Wiesbaden 2009, 118-26.

Jreis Navarro, L.M., El extraño viaje de Ibn al-Jațīb por los agitados llanos de Tāmasnā. Estudio y traducción de la riḥla, in Anaquel de Estudios Árabes 27 (2016), 81-10o. 
Hofer, N., Popularization of Sufism in Ayyubid and Mamluk Egypt, 1173-1325, Edinburgh 2015 .

Homerin, E., Saving Muslim souls: The Khānqāh and the Sufi duty in Mamluk lands, in MSR 3 (1999), 59-83.

Homerin, E., Ibn Abī Hağalah and Sufism, in N. Papoutsakis and S. von Hees, The sultan's anthologist-Ibn Abī Hağalah and his work, Baden-Baden 2017, 13-44.

Irwin, R., The Middle East in the middle ages: The early Mamluk Sultanate, 1250-1382, Carbondale 1986.

Knysh, A.D., Ibn Arabi in the later Islamic tradition. The making of a polemical image in medieval Islam, New York 1999.

Lirola Delgado, J., Ibn al-Jațīb, Lisān al-Dīn, in J. Lirola Delgado and J.M. Puerta Vílchez (eds.), Biblioteca de al-Andalus, iii, Almeria 2004, 643-98.

Lirola Delgado, J., and Á. López, Ibn al-Ḥâŷy al-Numayrī, Abū Ishāâ, in J. Lirola Delgado and J.M. Puerta Vílchez (eds.), Biblioteca de al-Andalus, iii, Almeria 2004, 642-3.

Manzano Rodríguez, M.A., Ibn Jaldūn, 'Abd al-Raḥmān, in J. Lirola Delgado and J.M. Puerta Vílchez (eds.), Biblioteca de al-Andalus, iii, Almeria 2004, 578-97.

Pomerantz, M.A., A Maqāmah on the book market of Cairo in the 8th/14th century: The "Return of the stranger" of Ibn Abī Hağalah (d. 776/1375), in N. Papoutsakis and S. von Hees, The sultan's anthologist_Ibn Abì Hağalah and his work, Baden-Baden 2017, 179-207.

Robinson, C., Lisān al-Dīn Ibn al-Khațīb, in J.E. Lowry and D.J. Stewart (eds.), Essays in Arabic literary biography: 1350-1850, ii, Wiesbaden 2009, 159-74.

Rosenthal, F., A history of Muslim historiography, Leiden 1968.

Talbi. M., Ibn Haldūn et l'Histoire, Tunis 1973.

Van Steenbergen, J., Order out of chaos: Patronage, conflict, and Mamluk sociopolitical culture, 1341-82, Leiden 2006.

Van Steenbergen, J., The amir Yalbughā al-Khāșșakī, the Qalāwūnid sultanate, and the cultural matrix of Mamlūk society: A reassessment of Mamlūk politics in the 136os, in JAOS 131/3 (2011), 423-43.

Van Steenbergen, J., On the brink of a new era? Yalbughā al-Khāṣṣakī (d. 1366) and the Yalbughāwiyah, in MSR 15 (2011), 117-52.

Velázquez Basanta, F.N., La Relación histórica sobre las postrimerías del Reino de Granada, según Aḥmad al-Maqqarī (s. XVII), in C. del Moral Molina (ed.), En el epílogo del islam andalusí: La Granada del siglo XV, Granada 2005, 481-554.

Velázquez Basanta, F.N., Nota bio-bibliográfica sobre Ibn al-Jațīb, in C. del Moral and F. Velázquez Basanta (eds.), Ibn al-Jațīb y su tiempo, Granada 2012.

Vidal Castro, F., Ibn al-Khațīb, Lisān al-Dīn, in $E I^{3}$.

Viguera Molíns, M.J. (ed.), El Reino Nazarí de Granada (1232-1492) Política, instituciones. Espacio y economía, Historia de España Ramón Menéndez Pidal, vols. viii-iii, Madrid 2000. 
Viguera Molíns, Maj. (ed.), El Reino Nazarí de Granada (1232-1492) Sociedad, vida y cultura, Historia de España Ramón Menéndez Pidal, vols. viii-iv, Madrid 2000.

Ženka, J., The great ruling family of the fourteenth century: Muṣāhara in the age of Ibn al-Khațīb, in Medieval Encounters 20 4/5 (2014), 306-39. 